\title{
Will Capital Reflows \\ Induce Domestic Interest Rate Changes?
}

\author{
by ANATOL BALBACH
}

E VALUATION of the performance of the U.S. economy in 1971 frequently has placed considerable emphasis on the impact of international capital flows on U.S. interest rates, especially Treasury bill rates. Similarly, prognostications about economic activity in 1972 have involved predictions of interest rate behavior which are heavily influenced by anticipated international capital movements. A typical description of events goes something like this:

(1) A large deficit in the U.S. balance of payments in 1971, particularly due to speculative conversion of dollar assets into assets denominated in foreign currencies, forced huge quantities of dollars on foreign central banks who in turn used them to purchase U.S. Government debt. These purchases bid up the prices of Treasury liabilities and thus depressed their yields. The arbitrage between the Treasury debt market and other credit and equity markets resulted in depressed yields on all U.S. interest-bearing securities.

(2) The devaluation of the dollar eliminated the anticipation of further capital gains accruing to holders of assets denominated in foreign currency and, when combined with the narrowing spread between U.S. and foreign interest rates, should cause the "repatriation" of speculative funds that moved abroad in 1971. This will then force foreign central banks to supply dollars which they will acquire by selling U.S. Treasury securities purchased earlier. Such a massive sale will depress security prices and raise yields, and again, through arbitrage, cause an increase in the yields of all debt and equity instruments in the United States. Therefore, interest rates are projected to rise in 1972 over and above what they would have been without large intemational capital movements.
Since monetary and fiscal policymakers consider interest rate levels important elements of their policy goals, the discussion of interest rate changes induced by international capital movements is not an idle exercise. It is a real problem which, through exercise of policy, may have substantial effects on the economy's performance in 1972-73.

This note is intended to explain, in a simplified manner, under what circumstances short-term international capital movements do or do not affect short term interest rates, and to examine the proposition that "repatriation" of dollar balances in the remainder of 1972 will significantly raise the level of short-term interest rates in the United States.

\section{Mechanics of International Capital Transfers}

International transactions take many forms and vari. ous degrees of complexity. Ultimately, however, if there is a net purchase of assets by residents of one country from residents of another, the payment takes place either as a transfer of a reserve asset, such as gold, SDRs, or dollars, or as an accumulation of demand deposits of the selling country's residents in the purchasing country's banks. The sellers are willing to accumulate these deposits only if it is profitable for them to do so. If not, then under a fixed exchange rate system these deposits can be sold to the selling country's central bank at a fixed price.

Suppose that international traders anticipate a depreciation of the dollar vis-à-vis other national currencies. This means that they could realize capital gains by converting their dollar assets into assets denominated in a foreign currency and converting 
them back into more dollars after the depreciation was realized. Thus, these individuals would use their existing dollar demand deposits, or convert other domestic assets into dollar demand deposits and proceed to buy foreign assets. These foreign assets may take the form of stocks, bonds, time or demand deposits, or even claims on goods. If the anticipation of dollar depreciation is generally prevalent, foreign recipients of these dollar balances will not be willing to hold them and will sell them to their central banks.

Traditionally, and in some cases by statute, central banks have converted these accumulated dollar deposits into short-term Treasury securities. Thus, a net capital outtlow from the United States results in the decumulation of dollar denominated assets and deposits by private individuals and corporations, and the accumulation of U.S. Treasury securities by foreign central banks. Conversely, an anticipation of dollar appreciation would induce a demand for dollar denominated assets. Since dollars can be purchased from foreign central banks at a fixed price, there will be a sale of Treasury securities by foreign central banks and a purchase of securities and deposits by private individuals and corporations.

It is these purchases and sales of Treasury securities by foreign central banks that have given rise to allegations that an outflow of dollars will raise security prices and lower interest rates, and that an inflow of dollars will lower security prices and raise interest rates in the United States.

\section{Dollar Outflows and Interest Rates in I971}

The situation in 1971 set into motion events as described above. In addition to the perennial excess of U.S. purchases of goods, services, and long-term capital over sales, yields on foreign short-term securities rose relative to those in the United States. This produced a further accumulation of dollar assets by foreign central banks and anticipations that foreign official agencies might stop buying dollars at the prescribed price. The possibility that the dollar might be devalued induced transactors to start converting ever-increasing amounts of dollars into currencies which were expected to appreciate. The rest is history. The German mark was floated on May 9,1971 , and similar action was taken soon thereafter by several strong-currency countries. On August 15, convertibility of the dollar into gold was suspended and, in effect, the dollar was permitted to depreciate according to market forces. On December 18, Smithsonian agreements were reached and the dollar was devalued with respect to gold and most foreign currencies.

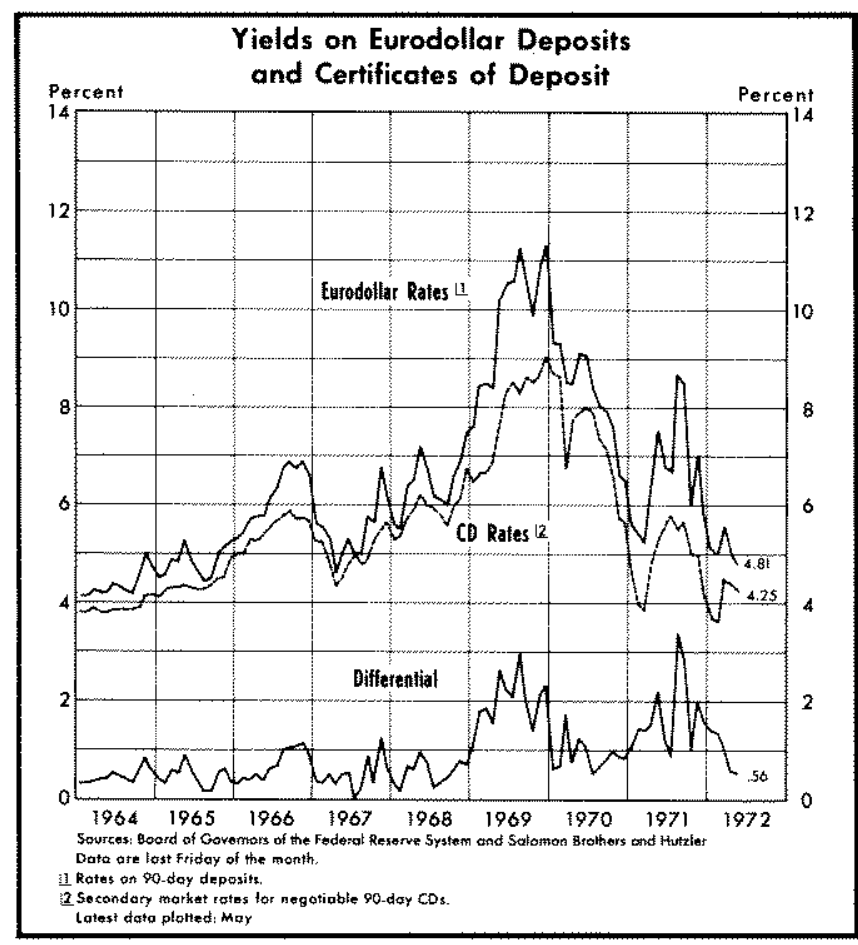

During this period foreign central banks accumulated $\$ 29.8$ billion and used them to buy $\$ 26.3$ billion worth of Treasury securities. There is no doubt that if these massive purchases had been net purchases of Treasury securities, that is, private buyers of foreign assets did not sell domestic securities or equities at the same time, the impact on the prices of these securities, and on interest rates in general, would have been significant. It would be tantamount to a sudden shift of $\$ 26.3$ billion from cash balances to interest-bearing debt. If, on the other hand, the purchasers of foreign assets sold Treasury securities to acquire funds, and foreign central banks ended up buying the same amount of securities, then the impact on interest rates would have been nil.

The true picture is somewhat closer to the latter case. Precise data on where and how capital transfers originate are not available, but it is possible to make an educated guess.

During 1971 U.S. private and governmental expenditures on purchases of goods and services and on gifts exceeded receipts from sales and gifts received by $\$ 2.8$ billion. Long-term capital investment abroad exceeded foreign long-term investments in the United States by $\$ 6.4$ billion. Thus, the "basic" balance - the amount of dollar balances accumulated by foreigners through these "basic" operations - amounted to $\$ 9.2$ billion. The total amount of dollars acquired by foreigners during 1971 - the liquidity balance was $\$ 22$ billion. Thus, short-term capital flows and 


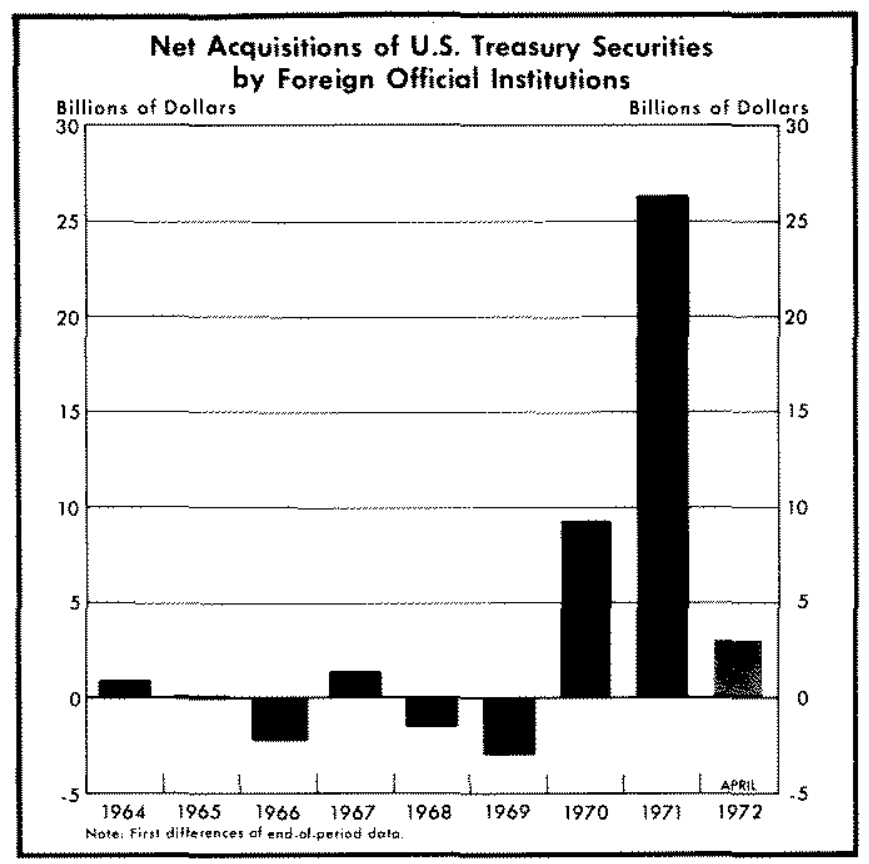

errors and omissions made up the difference $-\$ 12.8$ billion. Official foreign agencies accumulated $\$ 29.8$ billion, indicating that private foreigners not only sold to their central banks all that they had accumulated during the year ( $\$ 22$ billion), but transferred an additional $\$ 7.8$ billion of liquid U.S. assets to foreign official reserves.

If we assume that "basic" transactions are a result of price level differentials, long-term yield considerations, and various long-term private and government commitments, then the difference between the official transactions balance and the "basic" balance, or $\$ 20.6$ billion, was a result of short-term interest differentials and anticipated devaluation of the dollar. This estimate is obviously a very rough one, but it gives some insight into the magnitude of the so-called "speculative" outflows, which might reverse under changed conditions.

In considering the impact of these outflows on interest rates and the ease of the Treasury's financing of its debt, it becomes crucial to know whether these dollar balances were originally held in the form of currency and demand deposits, in some form of interest-bearing assets, or in equities such as stocks. Although there is evidence that equity transactions play a minor role in international capital transfers, let us assume that investors shift with ease from one capital market to another and are sensitive to yield differentials between equities and debt. If this is indeed the case, then it is possible to assert that the individuals and corporations engaged in international interest arbitrage, and who are able and willing to take advan- tage of anticipted exchange rate changes, were holding dollar denominated assets which were yielding some nominal rate of return. Thus, their purchases of foreign assets and the resulting foreign central bank purchases of U.S. Treasury liabilities were largely offset by a sale of U.S. debt and equity instruments. Such a set of transactions could have had only a minimal influence on short-term interest rates in the United States.

\section{"Repatriation" of Dollars in 1972}

Now we can turn to the oft-made statement that the expected return flow of dollars will cause U.S. interest rates to rise even higher in the remainder of 1972 than the levels they would otherwise reach.

In the first place, the reflow will occur only if interest rate differentials change sufficiently in favor. of the United States to offset anticipations of further dollar devaluation. These interest rate differentials have indeed been narrowing in favor of the United States. However, recent floating of the British pound and the resulting attempts to convert dollars into other European and Japanese currencies indicate rather strikingly that the dollar is still considered a "weak currency." At this time it appears that any monetary disturbance, irrespective of how far it may be removed from the actual strength of the dollar, raises the possibility of further dollar depreciation. Thus, the expected reflow may not take place.

Secondly, if the reflow does materialize, the crucial question is what will these returning dollar balances be converted into? If our rough figures are correct, these flows should amount to at least $\$ 20.6$ billion, and again, it is reasonable to assume that they would be converted into assets which bear some nominal return. Thus, the sale of Treasury securities by foreign central banks would be offset by the purchase of other debt and equity instruments by private individuals and corporations, and the impact on interest rates would be insignificant.

\section{Conclusions}

Any impact of international short-term capital movements on U.S. interest rates in 1971 depended on:

(1) whether the buyers of foreign currency denominated assets simultaneously sold dollar denominated debt and equity, and

(2) with particalar reference to the yields on Treasury debt, whether various debt and equity markets were effectively separate in the minds of transactors. 
The anticipated effects of a "repatriation" of shortterm capital in 1972, if it occurs at all, will depend on:

(1) what dollar denominated assets will be bought by the sellers of foreign assets, and

(2) the substitutability between different debt and equity instruments.

It seems reasonable to assume that individuals and corporations who engage in these "speculative" transactions are knowledgeable investors who do not keep large idle balances (idle in a sense that they do not earn any nominal return) and, therefore, their purchases of assets denominated in one currency are accompanied by sales of assets denominated in another. Given that the risk factors associated with equities have been rather small in the United States for the past thirty years, it is highly probable that the rates on Treasury debt are highly interdependent with the rates on other debt instruments and yields on equities. Thus, it is unlikely that capital outflows in 1971 were the major cause of the decline in Treasury debt rates or interest rates in general.

For these reasons, together with the recent concern that the dollar may still be overvalued, prognosticators of economic activity and policymakers who base their decisions on these predictions should be wary of assumptions that a "repatriation" of dollars will occur and, if it does, will cause an increase in U.S, interest rates.

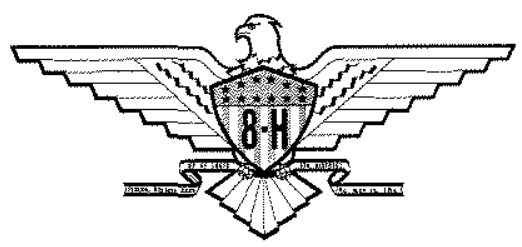

